\title{
Influence of SDR on RMB Internationalization
}

\section{Ran Wei}

School of Economics, Central University of Finance and Economics, Beijing, China

Received: 12 Oct 2020; Received in revised form: 08 Nov 2020; Accepted: 18 Nov 2020; Available online: 04 Dec 2020

(C2020 The Author(s). Published by Infogain Publication. This is an open access article under the CC BY license

(https://creativecommons.org/licenses/by/4.0/).

\begin{abstract}
In 2016, IMF officially announced that RMB was included in the currency basket of SDR, with the RMB accounting for $10.92 \%$ of the total currencies in SDR ranking the third place. The RMB'S accession to the SDR has played a role in promoting the RMB's internationalization status, opening up the international market and making the RMB become an international currency. However, at the same time, it is also necessary to clearly realize that the RMB's accession to the SDR does not have the final word as expected by the international community, and will not really increase the international holdings of RMB, which is, on one hand, restricted by "Triffin Dilemma" and "Mundellian Trilemma", and on the other hand, is as a result of the issue volume of the SDR and the inherent fragility of the real economy, resulting in the actual challenge to the internationalization of RMB. China has a long way to go to promote the internationalization of $R M B$, and there is still more work to be done.
\end{abstract}

Keywords - SDR, RMB, internationalization, Triffin Dilemma, Mundellian Trilemma.

\section{INTRODUCTION}

The full name of SDR is Special Drawing Right. It is known internationally as the "paper gold," which is an international currency reserve allocated by IMF (International Monetary Fund) according to the share of funds subscribed by the participating countries. In 1969, the IMF created a complementary reserve asset that could act as an international currency like gold and dollar, in order to address the defect in international liquidity and to make up for the shortfall in official reserves. By November 2015, the International Monetary Fund officially announced that RMB was included in the currency basket of SDR on October 1, 2016. Meanwhile, RMB became the third largest currency after it was included in the SDR. Among the currencies in SDR, dollar, euro, RMB, pound and yen account for $41.73 \%, 30.93 \%, 10.92 \%, 8.33 \%$ and $8.09 \%$ respectively. It is the first time since the euro was adopted that one currency has been added to the basket, and the first time that the currency of the emerging country has been included.

During the Second World War, the political situation was in turmoil, so number of currency groups appeared, followed by the fierce competition, leading to the devaluation of currency and market turbulence. After the Second World War, the U.S. dollar-centric Bretton Woods system came into being, including the International Monetary Fund (IMF) and WB (World Bank), which created the relevance of US dollar to gold, and other currencies link up with the dollar. This system adopted the fixed exchange rate. Since the United States had stronger economy and higher international position, the international holdings of US dollar are much higher than other currencies, naturally, the US dollar became an international currency. However, it also put higher requirements on the United States. The United States needed to maintain a long-term trade deficit in foreign trade in order to maintain the internationalization of the dollar, which in turn led to a reduction in the intrinsic 
value of the dollar, making it difficult for the dollar to maintain a fixed exchange rate against other currencies. At the same time, the core premise of the dollar as an international currency was that the currency value of dollar should be strong and stable, and it needed to maintain a long-term trade surplus. The surplus and deficit constituted a contradiction, which was known as the "Triffin Dilemma". Subsequently, the emergence of the dollar crisis caused the universal concern of international community to the international reserve status of the dollar and the reform of the international monetary system. At this point, the International Monetary Organization was in urgent need of an international reserve currency and new means of international circulation.

To solve this problem, in 1966, Pierre Schweitzer, CEO of IMF, published two plans of creating reserve assets. Plan one was to set up an affiliated agency--International Reserve Fund (IRF), issuing reserve unit and link it to gold. IRF was responsible for issuing the International Reserve Unit, and all Members shall consult with the IRF when they need to obtain the Reserve Unit that shall be loaned uniformly through IRF. The quota Reserve Unit borrowed shall be determined by the shares of the members in IRF. Plan two was to expand the automatic drawing rights of IRF. In the event of an international payment crisis, members can apply to the IMF for $25 \%$ shares of their original subscription when they joined the IMF, which is known as the "automatic drawing rights". This time, IMF wanted to expand the shares, which was called the "special reserve facility," predecessor to the "special drawing rights." In 1969, IMF Annual Meeting formally adopted the First Amendment to the International Monetary Fund Agreement, marking the official emergence of SDR, and SDR was formally introduced in August of the same year.

Robert Triffin, an American scholar, pointed out that as an international reserve and payment currency, it depended on the confidence of other countries in the economic strength and international liquidity of the currency issuer, regardless of whether the currency was linked to gold. The more frequently the country's currency is used internationally, the greater the amount of reserves in other countries, and the greater the country's external liabilities. Thereby affect the confidence of other countries in the economic prospects and international liquidity of the country. Based on this theory, if RMB becomes an internationally recognized currency, it needs to constantly expand the international payment deficit to maintain the continuous circulation of RMB in the international market or to be used as a reserve currency by the central banks of other countries. In 2008, China and South Korea signed a currency swap agreement. Since then, China has signed a series of agreements with many countries. Based on the currency swap agreement, RMB is held and reserved by the central banks of numerous countries.

In 2009, China opened the pilot program of RMB settlement of cross-border trade transactions in Shanghai and Guangdong, followed by other places nationwide. At the same time, China lifted a series of regional restrictions and added a number of related projects, enriching the form of trade. By 2012, cross-border trading companies were allowed to use RMB directly for international trade in accordance with state regulations. According to statistics, the amount of RMB trade settlement in 2009 was 3.58 billion yuan, increasing to 33.74 billion yuan in 2013 . Cross-border trade has been steadily promoted in size and achieved remarkable results.

In 2013, According to statistics of IMF, RMB ranked 13 th in world currency usage rate, and by 2015 , it ranked fifth in world currency usage rate. In terms of foreign exchange, in 2014, China's foreign exchange value accounted for $2.17 \%$ of global monetary expenditure, ranking second in the world. This is an important manifestation of China's currency going international and gradually gaining a foothold in the world.

China joining the SDR is another step toward internationalization. According to the statistics of 2016 RMB Internationalization Report, by the end of 2015, RII-the quantitative indicator of the RMB's international use, reached 3.6, increasing more than ten times in five years. And RMB settlement accounted for nearly $30 \%$ of the trade with China. At the same time, data shows that after China joined the SDR, the RMB exchange rate flexibility has been greatly enhanced, the two-way fluctuation has become more obvious, the pricing mechanism has been constantly revised and improved, and 
the combined use of the three foreign exchange policy tools: exchange rate intervention and control has also been strengthened.

\section{POSITIVE ROLE OF JOINING SDR}

Since China joined the SDR, RMB has been circulating around the world as an international reserve currency, which is a milestone for China's currency internationalization process. It fully demonstrates that the IMF has a full affirmation of China's economic strength 、 international status trade globalization and its voice in the world. It also indirectly demonstrates that China's economic development has made leaps and bounds. China's growing strength has ensured the progress of the internationalization of RMB, and in turn, joining the SDR has promoted the development of China's economy v trade and financial system.

Conducive to strengthening the international recognition of $\mathbf{R M B}$. Throughout the global development situation, the economic growth potential determines the future rise and fall of a country. Compared with developed countries, China's economic growth potential is more outstanding and remains stable in the medium and long term, which is also a major reason for China to attract foreign investment. RMB joining the SDR is more a declaration of the RMB's international status, which is equivalent to an affirmation of the currency's function and value, thereby attracting global investment, promoting international flows and increasing the international circulation of RMB. It has played a powerful role in promoting the internationalization of RMB, expanding the international influence of RMB, and promoting the circulation and use of RMB in the world. Of course, this is also a signal of external release, which shows that RMB, like other currencies such as the US dollar and euro, has a certain degree of international influence and has become an international reserve unit. It is of great significance for enhancing national self-confidence and international recognition. For sovereign wealth funds, in the preconditions of well-controlled risk, big holdings of RMB-denominated assets will be one of the main options in the future.

Conducive to deepening international cooperation and building an international platform. As the currency basket weighted by exchange rate, SDR has relative stability, and because SDR combines several exchange rates, it also reflects the development orientation of the global economy to a certain extent. If the currency basket can truly reflect the true value of variables such as imports and exports, international trade and economic scale, SDR can completely be the indicator of global economy. Therefore, multilateral talks and international cooperation around SDR and relevant weights will become the important contents among major economies. Although SDR does not have the ability to become the super-sovereign currency due to the constraints of systems and IMF, SDR has very good development prospect in the future. After it becomes the super-sovereign currency, SDR will also become an advanced form of cooperation for international community in the financial field, which will create a positive effect on the stability of exchange rate、 international trade and financial capital investment.

For China joined the SDR, on one hand, since Chinese enterprises can trade directly in RMB, the risk due to the exchange rate will be greatly reduced, which will greatly promote China's foreign trade and investment. And on the other hand, RMB joining the SDR will reduce the fluctuation frequency of the exchange rate, improve the stability of the exchange rate, and reduce the cost of trading in foreign currencies such as US dollar and euro, which will reduce the transaction cost of Chinese foreign trade enterprises. At the same time, RMB joining the SDR will also be conducive to China's international development strategies, such as "the Belt and Road", which will greatly simplify the currency exchange procedure, reduce the waste of human resources and other expenses, facilitate the cross-border cooperation, attract more countries to join "the Belt and Road" strategy, and encourage countries to strengthen communication and join hands to build a platform for cross-border cooperation. In a word, the convenient transaction settlement method has reduced the transaction risk, improved the transaction efficiency and reduced the transaction cost, and played an excellent role in promoting the development of China's economy and trade.

Conducive to the reform of China's financial system. RMB being included in the currency basket, while 
promoting the development of Chinese enterprises, will also inject a large number of funds for the domestic market, which will certainly promote the development of the Chinese market. With the improvement and perfection of the market, the domestic market will also be more open, which will help promote the reform of China's financial system. Taking the bond market as an example, when the currency of a country is held by other countries as the world's reserve unit, the main target of overseas asset allocation is fixed-income bonds. Driven by funds and under the international impact, China's bond market will be bound to become more mature. At the same time, it has helped to break down trade barriers, especially has had an important effect on the implementation of the strategy of "opening and action-forcing reform". Reform and development support each other forward. While improving the competitiveness of the financial sector, the efficiency of enterprises has been promoted, thus promoting the reform of the financial system.

\section{CONSTRAINTS AND CHALLENGES OF SDR TO RMB INTERNATIONALIZATION IN THEORY}

\section{Constraints of the "Triffin Dilemma" on RMB}

Since RMB was included in the currency basket of SDR, expectations have been high in China, believing that RMB has become an international currency. However, it cannot be denied that if the RMB is to become an international currency and an international reserve unit, it will be required to meet the condition of requirement of "freely usable". Similar to the previous dollar, it needs to maintain a long-term trade deficit to make it widely used in the international community, which is closely related to the international status of the economy of a country, even will have a negative impact on the economy in order to maintain the trade deficit. The trade deficit, in turn, leads to fluctuations in the intrinsic value of the currency of a country. At the same time, in order to maintain the stability of the currency of a country and maintain the trade surplus, this inherent contradiction has not been fundamentally resolved, and "Triffin Dilemma" still exists. Theoretically, it restricts the development of RMB in the international community. On top of that, suppose that if China wants to maintain a trade deficit, the first approach is to make net exports negative, such as purchasing foreign goods. As a developing country, China cannot support such a large trade deficit as the United Sates, which will limit China's development. The second approach is to liberalize the capital market and maintain the use of the RMB by selling domestic capital to foreign companies or individuals. However, China's capital market in the system is not perfect, and some measures to deal with the crisis for capital supervision are not perfect enough, so that China cannot timely deal with the uncertainties and risks brought by the liberalization of the capital market. The above contradictions have restricted the development of RMB internationalization.

\section{Challenges of the "Impossible Trinity" to monetary policy}

Impossible Trinity is a theory put forward by Paul Krugman, an American economist, on how to choose national policies in an open economy, which is also called the "trilemma". The main contents of this theory are: under the condition of an open economy, a country cannot realize the independence of monetary policy v the free entry and exit of capital and fixed exchange rate at the same time. At most, two of them can be satisfied, but the third one shall be abandoned, which is so called the perfect balance that we cannot achieve.

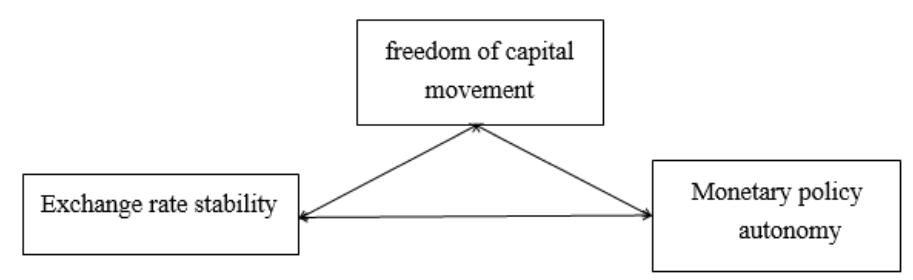

Fig.1: "Impossible Trinity"

From the domestic environment, if China wants to promote the internationalization of RMB, it shall open the market more vigorously, liberalize the capital control environment, fully invite the international floating capital, and maintain the liquidity of the capital. At the same time, as a large country in the reform and opening-up, China shall maintain the independence of the monetary policy while actively integrating into the world to advance the 
process of internationalization and increase its international influence. However, we know that if it maintains the independence of its monetary policy, the capital cannot completely flow, or the exchange rate cannot be stable. Imagine, if we make the capital to achieve a complete flow, then the market will be full of floating capital, which will certainly make the balance of payments of the country cannot be stable, but at the same time, because we maintain the independence of the monetary policy, the government's ability to intervene will be weakened, which means that China's exchange rate will not be able to be effectively controlled, and then the stability of the exchange rate cannot be guaranteed. This constitutes the impossible trinity. With the participation of RMB in the SDR, the domestic exchange rate will be more market-oriented, which means that the domestic exchange rate control space will be greatly reduced. At the same time, as a large developing country, China will not sacrifice its own development to seek the complete stable equilibrium of exchange rate. In order to stimulate investment and maintain the high-speed growth of economy, the low-interest rate stimulus policy will remain active for a long period of time, which will lead to a great reduction in the control effect of domestic macro-policy, and the Impossible Trinity will become more obvious.

\section{CONSTRAINTS AND CHALLENGES OF SDR TO THE INTERNATIONALIZATION OF RMB IN THE REALITY}

\section{Small Issuance Volume of SDR}

SDR is a monetary unit designed and established to maintain the Bretton Woods System. Up to now, SDR has played a certain role in stabilizing the foreign exchange market. However, when SDR was first established, it was used as an international reserve unit to stabilize the market and replace the US dollar as a single international currency. But, less than a few years after the SDR was issued, the Bretton Woods System was declared bankrupt. SDR ushered in an era of floating exchange rate, and its original purpose was difficult to achieve. At the same time, the allocation amount of SDR is relatively small. Up to now, its issuance volume is only 670.926 billion US dollars, which is only $20 \%$ of China's foreign exchange reserves. Such a small issuance volume is difficult to deal with the huge exchange rate fluctuations caused by political risks in various countries. Moreover, SDR lacks a substantial economic foundation. Today, in such a complicated world political structure, SDR is difficult to detach itself from the interconnected world and to avoid being affected by changes in the international structure, so the stability of exchange rate is difficult to realize in a real sense. China joining the SDR has changed the international status of RMB more in a sense. However, judging from the actual influence on the monetary system, it is difficult to achieve the expected effect by relying solely on the issuance volume of SDR and its stability.

\section{Limited international holdings of RMB}

RMB joining the SDR is the result of the rapid growth of China's economic strength and the gradual improvement of its international status since China's reform and opening-up, which fully demonstrates China's determination and attitude to actively integrate into the international community and commit itself to becoming a major international power. However, joining in the currency basket does not mean that RMB has become the world currency since then. Whether a currency can truly become an international reserve unit and really have international influence depends on whether the holdings of such currency in the international community achieve a scale effect. Even the voice of a country in the IMF is closely related to the amount of capital holdings. We know that the weight of RMB joining the SDR is close to $11 \%$, while that of the dollar reaches $42 \%$, and the euro is $31 \%$, so our international influence is limited in numerical terms. Moreover, the weight index of the SDR of a country does not fully represent the share of the currency in the foreign exchange reserves of various countries. According to the IMF data, by mid-2017, the world's official reserve of the RMB was 99.36 billion US dollars, accounting for just $1.07 \%$ of the world's total foreign exchange reserves, while the United States accounted for $41.73 \%$ in SDR and $64 \%$ of the foreign exchange reserves of other countries. Moreover, the current IMF system restricts the international influence of the SDR on the RMB. IMF relies on the share of member countries to determine voting rights and SDR shares, that is, the currency composition of 
the SDR has nothing to do with the IMF's decision-making power. As of December 2017, the United States still had 831,407 votes, accounting for $16.52 \%$ of the total votes, still maintaining a $15 \%$ veto threshold for decisions on major issues. Although both the RMB's entry into the SDR and the 2010 share reform program helped China win 30, 2694 votes and $6.09 \%$ voting rights in the IMF, it was still slightly lower than Japan's (6.15\%).

\section{Inherent fragility of the real economy}

While RMB was included the currency basket, China's "13 $3^{\text {th }}$ Five-year Plan" has also just begun. Five ideas of "innovation, coordination, green, opening up and sharing" and five tasks of "cutting overcapacity, cutting inventory, deleveraging, reducing cost and improving weakness" were set up. It is expected that in 2020, that is, through 10 years of time, GDP and per capita income of urban and rural residents can double, which means that the "middle income trap" can be successfully crossed. To achieve this goal, China's economic growth is required to be maintained at an average annual rate of more than $6.5 \%$, and especially the components of scientific and technological progress shall make over $60 \%$ contributions to the economic growth. However, nowadays, China's real economy is still facing many problems, especially the rapid expansion of virtual economy in recent years, and the crowding-out effect on the real economy is even worth the attention of the whole society.

According to Figure 2, the author has analyzed the year-on-year growth rate of real GDP and the trend of fictitious economic factors, hoping to get a certain economic connotation. Since the reform and opening-up, China's rapid economic development has created one "China miracle" after another. After the financial crisis in 2008, China's economic development has entered a new stage, and the problems behind the long-term rapid economic growth are gradually exposed. The financial crisis has led to a sharp contraction in demand for Chinese exports in developed countries, which was a major blow to
China's export-oriented economy, directly leading to a drop in China's net exports from 9\% of GDP to less than $3 \%$, and causing a sharp slowdown in economic growth. After the GDP growth rate reached $12.1 \%$ in the first quarter of 2010, it fluctuated downward. It was below "7" for the first time in the third quarter of 2015 with a year-on-year growth rate of $6.9 \%$ of China's GDP, which still failed to reverse the downward trend. China's overall economic situation is grim, and there has been a gradual decline in the economic growth rate, causing problems such as overcapacity, real estate bubble and high leverage ratio of government and state-owned enterprises. In contrast to the trend of virtual economic factors, before the financial crisis in 2008, the change was relatively smooth. After the financial crisis, there was a sharp rise, and in a fixed time range, it was still showing an upward trend. From the single representation of representative index capital market of virtual economic factors, from 2006 to 2007, there was a big bull market in China's stock market. The main reason was that the banking system had sufficient funds, resulting in a large amount of money flowing into the stock market, and sufficient market liquidity resulted in market overheating, pushing up the market index with the Shanghai Composite Index reaching 6000 points; since China's securities companies rose from 2016, the market sentiment has been high. Investors increased the allocation of financial assets by the means of "adding leverage", and the money flowed from the real economy to the virtual economy. With the bursting of the bubble, "thousands of stocks fell" and other market collapse phenomenon emerged, and the economy was hit hard. In a word, it can be seen from the trend of virtual economy and real economy that there is obvious deviation between the two trends, which has typical characteristics of "deviation between the reality and virtuality". It also shows the inherent fragility of China's real economy. 


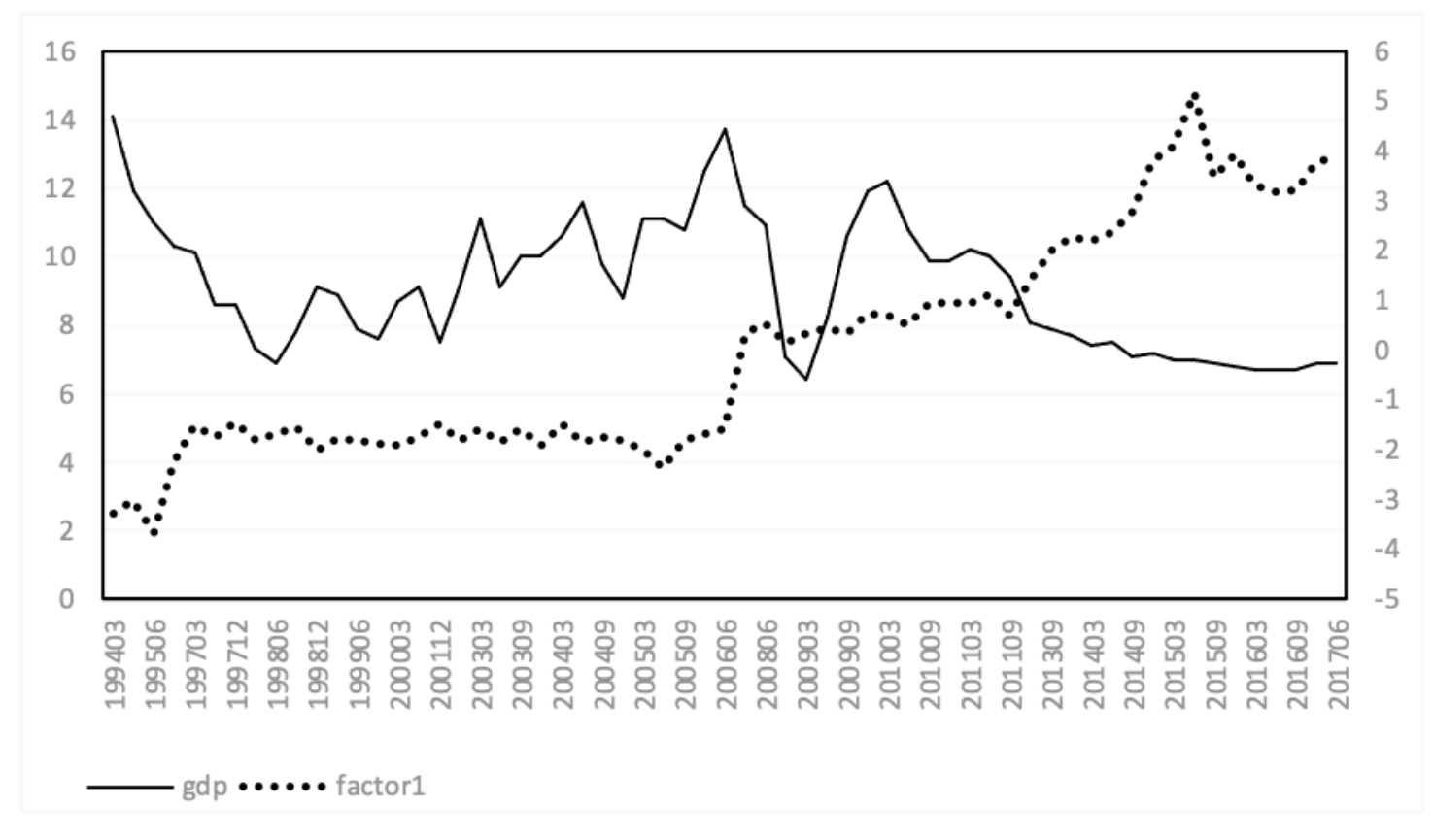

Fig.2: The trend of real economy and virtual economy

\section{SOME INSPIRATION TO THE INTERNATIONALIZATION OF RMB}

First, establishment risk prevention mechanism. After the RMB's entry into the SDR, as the opening-up to the outside world deepens, the Chinese market also faces higher risks, which also puts forward higher requirements for China's risk control. The short-term profit-seeking international capital has the speculation behavior, and this part of capital will bring huge risks when entering China. Therefore, prudently and abstemiously control the capital inflow to guarantee the security of the capital market is particularly important. For our regulators, attention should be paid to the co-operation and co-management among financial departments, timely blocking the risks and avoiding regulatory blind spots and regulatory loopholes. Firewalls shall be set up to implement adjustment measures such as handling fees for foreign exchange transactions so as to enhance the ability to defend against risks.

Second, strengthen the development of the real economy. A strong real economy is the driving force and fundamental guarantee of the economic strength of a country, and it is the pillar of a country, playing the role of a mainstay. Facing the impact of globalization and standing on the crossroads of rapid economic development, China shall make a good choice to reduce the excessive expansion of the virtual economy and prevent the impact of the virtual economy on the real economy. Strengthen the supervision measures, perfect the repair mechanism, strive to improve the virtual economy vitality, and at the same time, enhance the real economy power and promote the core competitiveness of the real economy. Improve the supporting role of science and technology in economic development, realize industrial transformation and upgrading, and accelerate the process of internationalization.

Finally, deepen the reform of the financial system. For example, in monetary policy regulation, China should speed up the reform of monetary policy regulation system. In the operation mechanism of monetary policy regulation, China uses the administrative mechanism to carry out the direct regulation and control, and the legal deposit reserve ratio mechanism, open market operation, control of the benchmark interest rate of deposit and loan, and new loan scale are commonly used means, but these means do not fully meet the requirements of the market mechanism; to a large extent, China's monetary policy regulation is still focused on financial institutions, and taking financial market as the focus of regulation is still under discussion; 
so far, we have not effectively formed the exchange rate policy and interest rate policy transmission mechanism as a regulation tool of monetary policy under the market economy condition, and lack of relevant control experience. After RMB joined the SDR, the reform of these institutional mechanisms shall be accelerated, the financial self-regulation mechanism shall be improved, and the regulation ability of monetary policy shall be enhanced, so as to realize all-round and multi-angle regulation and control, and effectively curb the monetary problem.

\section{REFERENCES}

[1] Axel Dreher.(2006).Does globalization affect growth? Evidence from a new index of globalization. Applied Economics .

[2] Barry,Rachita,Ugo Panizza.(2011).Capital account liberalization, financial development and industry growth: A synthetic view.Journal of International Money and Finance.

[3] Ben S Bernanke.(2017).Federal Reserve Policy in an International Context.IMF Economic Review

[4] Lagoarde-Segot T.(2017).Financialization: Towards a new research agenda.International Review of Financial Analysis 51:113-123.

[5] Lapavitsas.C.(2009).Financialised Capitalism: Crisis and Financial Expropriation.Historical Materialism 17(17):114-148.

[6] Lin J. Y. \& Zhang P.(2007).Development Strategy, Optimal Industrial Structure and Economic Growth in Less Developed Countries.General Information.

[7] Mark Illing, Ying Liu.(2006).Measuring financial stress in a developed country: An application to Canada. Journal of Financial Stability.

[8] William R. White.(2008).Past financial crises, the current financial turmoil, and the need for a new macrofinancial stability framework. Journal of Financial Stability . 